\title{
COMPARATIVE STUDIES OF COVID-19 IMPACT ON STUDENTS’ VIEWS ON DIGITAL HIGHER EDUCATION
}

\author{
Andreas Ahrens \\ Hochschule Wismar University of Applied Sciences: Technology, \\ Business and Design, Germany \\ Jeḷena Zaščerinska \\ Centre for Education and Innovation Research, Latvia \\ Parulkumari P Bhati \\ Nirma University, India \\ Mihails Zaščerinskis \\ Centre for Education and Innovation Research, Latvia \\ Anastasija Aḷeksejeva \\ Centre for Education and Innovation Research, Latvia
}

\begin{abstract}
Higher education sector has been significantly adapting to the new situation created by the COVID-19 pandemic. Despite students are often referred to, students are rarely at the centre of the concerns being raised. The research aim is to compare students' views on digital higher education in light of COVID-19 underpinning the identification of issues in digital higher education in light of COVID-19. The research implies theoretical and empirical methods. The exploratory empirical study was carried out. Semi-structured interviews serves as the data collection method. Content analysis was applied to the obtained data for data processing. The theoretical analysis allows finding that digital environment in higher education is not limited by only a technical aspect of its organisation. Digital environment also implies students' health, financial and economic situation, etc. The empirical findings contribute to the conclusion that digital higher education in light of COVID-19 is negatively evaluated by students. The most common issues faced by students are identified. The research question is newly formulated. Directions of further research are proposed. The novelty of the paper is presented by the identified issues in digital higher education in light of COVID-19.
\end{abstract}

Keywords: Comparative studies, COVID-19 impact, digital higher education, issues, sampling, students' view.

\section{Introduction}

The pandemic Covid-19 has spread over the whole world. It was the first identified in Wuhan, China, on December 31, 2019. The first death by COVID19 was the 61-year old man in Wuhan, China, 2020. World Health Organisation 
Ahrens et al., 2021. Comparative Studies of Covid-19 Impact on Students'Views on Digital Higher Education

(WHO) declared COVID-19 to be a pandemic in 2020. February 11, 2020, the World Health Organisation (WHO) proposed the official name of the virus as COVID-19.

The global outbreak of the COVID-19 pandemic has led to the unprecedented changes in people's lives. Many people have experienced rapid transformations from conventional prototype to digital prototype (Ramar \& Zaščerinska, 2015) of many aspects of their lives: working, education, shopping, travelling, etc. The pandemic COVID-19 has compelled the human society to maintain social distancing. The spread of the pandemic COVID-19 has significantly disrupted the higher education sector which is a critical determinant of a country's economic future. Also, education is considered as an essential human virtue to humanize a human being (Ramar \& Zaščerinska, 2015). Occurrence of COVID-19 has impacted more than 120 crores of students across the planet.

Higher education sector has also been significantly adapted to the new situation created by the COVID-19 pandemic (Ahrens \& Zascerinska, 2021). Higher education is conventionally delivered by higher education institutions. The terms "higher education institutions", "universities", "academies" and other names are used synonymously in this work. Also, by the term "higher education", higher education's educational environment is meant. Pressed by the COVID-19 pandemic, higher education institutions were able to rapidly change (Ellis-Haque, 2020). Almost overnight, university staff were able to start online working and teaching from home (Ellis-Haque, 2020). Online working and teaching from home have been identified as the new normal (Ellis-Haque, 2020). However, the work put into achieving this should not be under-estimated (Ellis-Haque, 2020). These intensive and immersive digital educational opportunities make the student learning more productive, informative and creative (Hariharan, Zascerinska, \& Swamydhas, 2013). Hence, students are revealed to be the key participants (Ahrens, Purvinis, Zaščerinska, \& Andreeva, 2015). For example, higher education institutions are closed if they do not enroll enough students. If students are not satisfied with the higher education delivery at one higher education institution, than they can change to another one, even if it is located in another country (Ahrens, Grünwald, Bassus, Andreeva, Zaščerinska, \& Melnikova, 2018). Consequently, the students' primary role in higher education cannot be diminished. Against students are referred to, students are rarely at the centre of the concerns being raised (Timmis, 2020). Huge differences in experience persist both within and between different country contexts, largely driven by existing inequalities (Timmis, 2020).

The research aim is to compare students' views on digital higher education in light of COVID-19 underpinning the identification of issues in digital higher education in light of COVID-19. Both theoretical and empirical methods are used 
in the present research. Theoretical sources were anaylszed, theoretical modelling was implemented within the theoretical investigation (Ahrens, Zascerinska, \& Melnikova, 2019). The empirical study was exploratory. The aim of the exploratory study was to propose new research questions. Data collection was based on semi-structured interviews. The obtained data were processed via content analysis. The novelty of the paper is presented by the identified issues in digital higher education in light of COVID-19.

\section{Conceptual Framework}

Digital higher education, also referred as digital environment, is centred on teaching and learning (Ahrens \& Zaščerinska, 2012). Staff and students have a responsibility to work together to ensure that online sessions, whether live or asynchronous, are inclusive and that all students are encouraged to contribute equitably and their contributions are respected (Davies, 2020). Among the many lessons learned from the COVID-19 pandemic is the power of technology to connect us wherever we are (Visco, 2020). Advanced communication tools have the power to bring us together, keep us engaged and ensure we remain on a positive track toward our career and personal goals (Visco, 2020). Increased use of technologies and digital services can have an impact - both positive and negative - on students' mental, physical, social and emotional health (Davies, 2020). The on-line model which universities have adopted is designed to support staff-student and student-student interaction and engagement, in order to mitigate the risk of students feeling isolated (Davies, 2020). Using mobile messaging, push notifications, and other mobile-first strategies is a "must" for universities looking to connect with students who today are living almost constantly online (Visco, 2020). If remote learning solutions do not function across devices, student participation is likely to suffer as students struggle to connect, submit assignments, attend lectures and events and keep up with campus life (Visco, 2020). For the teaching delivery, digital environment in higher education should be ensured by the availability of teacher's and students' computers and other electronic equipment, the Internet and other necessary infrastructure such as mobile-first (Visco, 2020), and the required software on both teacher's and students' computers and other electronic equipment.

\section{Methodology of the Empirical Study}

The methodology of the empirical study was based such the key elements as the question, purpose, sample and methodology of the empirical study.

The question that guided the empirical study was formulated: What are students' views on digital higher education in light of COVID-19? The empirical 
study was aimed at comparing students' views on digital higher education in light of COVID-19. It is worth pointing that individual's view is defined as his/her knowledge, skills and attitudes to a phenomenon (Ahrens, Zaščerinska, Hariharan, \& Andreeva, 2016). The knowledge, skills and attitude are interrelated (Ahrens \& Zaščerinska, 2015a). The inter-connections between knowledge, skills and attitude allow identifying individual's attitude to be the key element of the individual's view on a phenomenon. Traditionally, attitude is differentiated into positive, neutral or negative as illustrated in Figure 1 (Ahrens \& Zaščerinska, 2014a). However, for the study purposes, only positive and negative attitude, or, in other words, view will be considered.

\section{Attitude}

Positive

Neutral

Negative

Figure 1 Differentiation of Attitude (Ahrens \& Zascerinska, 2014a)

The empirical study was conducted in November-December 2020. The principles, namely sample appropriateness, sample sufficiency, and sample confidence (Ahrens \& Zaščerinska, 2015b), influenced the sampling of the empirical study. The sampling process proceeded (Ahrens \& Zaščerinska, 2016) from Phase 1 Identification: the identification of the target population and its accessibility through Phase 2 Formation: building the sample by specifying the sampling frame and its homogeneity, deciding on sample size, considering timing and types of sample (simple random, systematic and stratified sampling, etc), selecting the sample, etc. to Phase 3 Evaluation: the sample evaluation by nonstatistical methods such as internal and external evaluation. The sample size was formed by the factors (Ahrens \& Zaščerinska, 2014b). The factors were divided into external and internal factors (Ahrens \& Zaščerinska, 2014b). External factors focused on surroundings' and resources' factors. These were the access to the sample and resources. The resources' factors implied time, personnel and its competences and experiences, technical support, and measurement procedures, (Ahrens \& Zaščerinska, 2014b). The internal factors referred to the researcher (Ahrens \& Zaščerinska, 2014b): aims of research, aims of generalisation, research methodologies, educational research paradigm, motivation, interest, skills, and experience (Ahrens \& Zaščerinska, 2014b).

The sample of the present empirical study was composed of 10 respondents: three international students from Germany, two domestic students from Latvia, one domestic student from India, one domestic student from the USA, two 
domestic students from the UK, and one domestic student from South Africa. For the confidentiality purposes of the present research, the respondents' names and surnames were coded as R1, R2 and R3 (Respondent 1, 2 and 3 from Germany), R4 and R5 (Respondent 4 and 5 from Latvia), R6 (Respondent 6 from India), R7 (Respondent 7 from the USA), R8 and R9 (Respondent 8 and 9 from the UK), and R10 (Respondent 10 from South Africa). All the respondents obtained or were obtaining different degrees in different scientific fields in different countries and cultures. In regard to the international students, it should be pointed that Germany is famous with enrolling students from such countries as India, China, Egypt, etc (Ahrens, Gruenwald, Bassus, Zaščerinska, \& Melnikova, 2017; Ahrens, Grünwald, Bassus, Andreeva, Zaščerinska, \& Melnikova, 2018; Gruenwald, Ahrens, Zaščerinska, Melnikova, \& Andreeva, 2018). The international students in Germany have to keep a certain amount of money for living in the country and are allowed to work not more than 20 hours per week. The international students in Germany mostly live in a dormitory or rent a flat. The domestic students who took part in the study in the other countries mostly they lived in the parents' flats and houses. They are allowed to work in accordance with the state legislation (about 40 hours per week) if they can manage to combine studying and working. Working experience of the participating respondents was different, too. The respondents represented different professional cultures such as banking, education, business, etc. Hence, the respondents' socio-cultural context (age, working field, the field of study, mother tongue, etc.) was heterogeneous. Further on, the respondents with different cultural backgrounds and diverse educational approaches participated in the study. Thus, the study's sample was multicultural. Such the sample composition highlighted the significance of the analysis of responses received from each respondent (Luka, Ludborza \& Maslo, 2009). The respondents' different cultural and educational backgrounds allow examining the process of the construction of the knowledge and opinion (Krueger, \& Casey, 2000).

A generally exploratory methodology is proposed. Here the exploratory relates to being open at the outset of the study. The exploratory study was aimed at answering the questions and generating new research questions. This will allow flexibility in the assessment of digital higher education. Explanatory elements will relate to identifying common patterns of association relating to the success of embedding digital into higher education. The study employed the implementation in three main steps: conceptualisation, case studies, and culmination. The study started with the conceptualisation step (Phillips, 2006) during which a comprehensive literature review was undertaken to inform refined research methodology and tools. This step described digital higher education. The second step was case studies collecting data in semi-structured interviews with students across selected countries. The third step elaborated on the study findings in the 
Ahrens et al., 2021. Comparative Studies of Covid-19 Impact on Students'Views on Digital Higher Education

form of case studies to feed into the development of new research questions on digital higher education for higher education providers, stakeholders, and practitioners.

The data were collected via the semi-structured interview. The semistructured interviews were used as the researchers had obtained the initial knowledge on the research field (Kroplijs, \& Raščevka, 2004). The semistructured interviews were conducted with the respondents in different time. The semi-structured interviews were based on the following question: What is your view on digital higher education during the pandemic COVID-19? The semistructured interviews were recorded and detailed notes made. The semi-structured interviews were relatively open and exploratory until novel issues stopped emerging. Full transcripts were made, and thematic analysis was carried out to elucidate common themes, and topics of discussion.

The collected data were pre-processed via selection of data sets and data preparation (partition, localisation and cleaning) (Ahrens, Zaščerinska, Melnikova, \& Andreeva, 2018). The collected data were further processed via content analysis (Ahrens, Foerster, Zaščerinska, Wasser, 2020). Two types content analysis were carried out (Mayring, 2014), namely the structuring content analysis and the summarizing content analysis. By the structuring content analysis, categorising the data in accordance to the previously determined criteria is meant (Budde, 2005). The summarizing content analysis intends to reduce the material in order to preserve the essential contents in a manageable short text (Mayring, 2004, p. 269). Pedagogical interpretation was applied in the proposed study. Pedagogical interpretive paradigm is conventionally used by the researcher who demonstrates a practical interest in the research question (Cohen, Manion, \& Morrison, 2003). The interpretive paradigm assists in the analysis of the social building of the meaningful reality. Interpretation allows the meaning to appear. The researcher serves as the key interpreter (Ahrens, Purvinis, Zaščerinska, Miceviciene, \& Tautkus, 2018) of the meaning.

\section{Results of the Empirical Study}

R1 explained that his computer broke in the middle of the semester. Due to the pandemic COVID-19, he could not find any job to earn some money for buying a computer. His parents could not support his buying a new computer.

R2 wished to updated his computer as his computer had not enough space for installing a specific software to be used for his engineering studies. The shop staff offered him to join the on-line queue for a couple of months as the demand for new computers as well as spare computer parts was higher that the offer.

R3 also had some computer problems and applied for a scholarship in order to spend the scholarship money for buying a new computer. 
Respondents R4 and R5 point that the transfer of studied from on-campus format to the digital one requires more computers per family as well as space for taking part in on-line classes. The respondents explained that if a family has a couple of children who learn at school and/or study at university, the classes usually are given at the same time. Consequently, each family's child, who learns or studies, requires an own computer with the needed infrastructure as well as a separate room. Very often the child's parents also work from home, and the parents need their own computer and equipment for working as well as the room. Both respondents stressed that due to people who mostly worked from home, the Internet network was overloaded, and, consequently, the connection for the online classes was lost, even for a couple of times per one class. Both respondents could not find any job as many companies in the country were on lockdown, and many employees lost their jobs. In that situation, buying a computer for each family member was a demanding task for the family budget.

R6 indicated that India is a large and diverse country. In India, there are about 38 million student population in about 1000 universities and 47,000 colleges. The respondent presented a study of NCERT (2020). The study indicates that approximately $27 \%$ of the students do not have access to smartphones/laptops to participate in online classes (NCERT, 2020). Imparting online education depends on the availability of technical infrastructure that varies in India over the length and breadth (NCERT, 2020). The respondent highlighted that adopting complete online learning is also becoming a health hazard for students. Online education is a reason of such diseases like obesity, sleep disturbances, spinal problems, anxiety, and depression (NCERT, 2020). RIS1 assumed that almost 43 lakh are disabled students across the states in India. There is a danger that the disabled students may drop out as they are not able to cope with online education. The respondent pointed that WhatsApp is the dominant mode of online education delivery. Phone calls between teachers and students are also intensively used. Online teaching is an issue for teachers as half of the teachers faced problems with expensive data and slow internet (NCERT, 2020). Due to these issues, almost 84\% teachers difficulties with online teaching (NCERT, 2020). The respondent also underlined that many housholds have a limited access to the technical infrastructure: only one tenth have access to the computer, and one fourth - to internet facilities (NCERT, 2020). Students digital literacy (computer and internet) has to be increased: one fourth of the students obtain the knowledge of computer and internet use (NCERT, 2020). Access to the internet in rural and urban India is of a vast disparity. While in the urban areas, the access and use of the internet reaches $43 \%$, in the rural areas only $16 \%$ benefit from it (NCERT, 2020). In rural areas, computers are used hardly $10 \%$ while $32 \%$ - in urban areas (NCERT, 2020). This disparity poses a huge challenge for providing online education in India. Such a situation deepens the regional digital divide across the 
India states: in the poor states, household access to the internet is particularly low, and high - in the developed states. Such digital divide raises a dual challenge for poorer states: on the one hand, the poor states are already burdened by poor infrastructure and educational achievements, and, on the other hand, the poor states now face the issue of the quality of online education (NCERT, 2020). The respondent highlighted another aspect of online education such as the risk of cyber-bullying, including children's privacy, online discrimination, online sexual abuse, and harmful content. The respondent consider that online education should be safe.

R7 pointed that $93 \%$ of low-income teens say they have access to a smartphone and $75 \%$ have access to a computer at his university. The respondent opined that Students do not check their email that often, and do not open every email they receive. They are skilled at skimming subject lines and preview text and know how to use filters to organize their inbox based on preferences, so there is no guarantee a promotional email will be opened, let alone read in full. The respondent revealed that university inboxes are filled with emails from peers, professors, departments, programs, and campus activities-many of which send emails too frequently. And personal inboxes are filled with so much more. Students are a little lost in the crowd. Many students roll their eyes at poorly formatted emails, lengthy and long-winded emails, and emails that are followed by slightly different twins with correct event times or campus locations.

R8 assumed that students would get a non-qualitative university experience due to on-line learning. The students seem to lack the material resources needed for online classes. Before the COVID-19 pandemic, students could do temporary, casual and part time jobs. However, the COVID-19 pandemic forced the rapid collapse of the student economy. Students' unemployment situation also means more students' stress about paying their rent or bills. Such situation provoked students to stay on in the family home. However, home university may be unsuitable: students need a quiet place in the house for study. As many working activities are transferred to home office, another issue is to have a reliable internet connection. Against this background, there are some students who may like using online education. One of the aspects is online discussions. Some students are eager to take part in online discussions presenting and argumenting their opinion due to the relative anonymity of online discussions. Another aspect is that move to online learning also makes higher education more attractive for disabled students. Online education does not require disabled students to get to buildings on campus which might be physically difficult for such students. There are also mature students who prefer flexibility of online learning. The respondent emphasized accommodation bubbles where students will not have a social distance. 
R9 stressed that 'fluid, flexible timetables' are an advantage for a student. The respondent disclosed that students need more support in many aspects from their family, community or workplace. The respondent also noted that the students' group became a broader age-range, more diverse nationally and culturally, on-campus students mixing with distance students.

R10 faced difficulties in access to both infrastructure and connectivity since they are often severely limited. If the systems and processes adopted by universities are too technocratic, a student cannot participate alongside your fellow students in an online zoom class because there is no access to the Internet. These kind of situations increase students ' feeling of anxiety and isolation. R10 also reported that some students identified that they were victims of racism as they were not safe even in an environment which was supposed to be welcoming and tolerant.

\section{Findings of the Empirical Study}

Due to the structuring content analysis of the collected data, issues in digital higher education have been identified. The findings of the empirical study are presented in Table 1.

The implementation of the summarizing content analysis reveals that students' negative view on digital higher education in light of COVID-19 prevails.

Table 1 Issues in Digital Higher Education in Light of COVID-19 from the Students' View (the authors)

\begin{tabular}{|c|c|c|c|}
\hline \multicolumn{4}{|c|}{ Digital higher education } \\
\hline $\begin{array}{l}\text { Teacher's and } \\
\text { students' } \\
\text { electronic } \\
\text { equipment }\end{array}$ & $\begin{array}{l}\text { The Internet and } \\
\text { other necessary } \\
\text { infrastructure }\end{array}$ & $\begin{array}{l}\text { Software on both } \\
\text { teacher's and } \\
\text { students' electronic } \\
\text { equipment }\end{array}$ & Other issues \\
\hline $\begin{array}{l}\text { A broken } \\
\text { personal } \\
\text { computer } \\
\text { (1 respondent) } \\
\text { No access to } \\
\text { smartphones/ } \\
\text { laptops (3 } \\
\text { respondents) } \\
\text { Phone calls } \\
\text { between } \\
\text { teachers and } \\
\text { students } \\
\text { (1 respondent) }\end{array}$ & $\begin{array}{l}\text { The overloaded } \\
\text { Internet } \\
\text { connection } \\
\text { (4 respondents) } \\
\text { Lack of technical } \\
\text { infrastructure } \\
\text { (2 respondents) } \\
\text { Expensive data } \\
\text { (1 respondent) } \\
\text { Slow internet } \\
\text { (1 respondent) } \\
\text { Limited access to } \\
\text { internet facilities } \\
\text { (1 respondent) }\end{array}$ & $\begin{array}{l}\text { Space limit on a } \\
\text { personal computer } \\
\text { for installing the } \\
\text { required } \\
\text { ( } 1 \text { respondent) } \\
\text { Use of WhatsApp } \\
\text { ( } 1 \text { respondent) }\end{array}$ & $\begin{array}{l}\text { No job or similar for getting } \\
\text { the money for a new/repaired } \\
\text { computer ( } 4 \text { respondents) } \\
\text { A queue for buying or } \\
\text { repairing a computer } \\
\text { (1 respondent) } \\
\text { No own room/space for } \\
\text { taking part in on-line classes } \\
\text { (1 respondent) } \\
\text { No personal computer for } \\
\text { each member in a family } \\
\text { (1 respondent) } \\
\text { a health hazard for students } \\
\text { ( } 2 \text { respondents) }\end{array}$ \\
\hline
\end{tabular}


Ahrens et al., 2021. Comparative Studies of Covid-19 Impact on Students'Views on Digital Higher Education

\begin{tabular}{|l|l|l|}
\hline & Low use of the \\
internet in rural & & disabled students' inability to \\
areas & cope with online education \\
(1 respondent) & (1 respondent) \\
infrastructure & (1 respondent) & lack of knowledge of \\
& computer and internet use \\
& (1 respondent) \\
& quality education on a virtual \\
& platform (2 respondents) \\
& cyber-bullying on the Internet \\
& (2 respondents) \\
& poorly formatted university \\
& emails to students \\
& (1 respondent) \\
& accommodation bubbles \\
& (1 respondent) \\
\hline
\end{tabular}

Source: The authors.

\section{Conclusions}

The theoretical analysis defines that digital environment in higher education is not limited by only a technical aspect of its organisation. Digital environment also implies students' health, financial and economic situation, etc. The empirical findings allow concluding that digital higher education in light of COVID-19 is negatively evaluated by students. The most common issues faced by students are the overloaded Internet connection (4 respondents), no job or similar for getting the money for a new/repaired computer (4 respondents), and no access to smartphones/ laptops (3 respondents). Despite the difficulties met by students, the positive aspects of digital higher education highlighted by students include disabled students' benefits from flexibility of online learning (2 respondents), students' confident participation in on-line discussions (1 respondent), nationally and culturally diverse students' group (1 respondent).

Some limitation in the study have been outlined. Participation of only 10 respondents from few countries in the conducted semi-structured interviews is recognised as a limitation. The use of one method for data collection is also determined as a limitation. The new research question has been put forward: What is a training for teachers who organize a digital environment in higher education to be based on students' health, financial and economic situation as well as other aspects? Future research will involve more respondents such as university teachers, employees, local government, and wider community into the empirical study. The search for methods of data collection is planned, too. Comparative studies on digital higher education in different countries are of great interest in the scientific community. 
SOCIETY. INTEGRATION. EDUCATION

Proceedings of the International Scientific Conference. Volume V, May $28^{\text {th }}-29^{\text {th }}, 2021.17-29$

\section{References}

Ahrens, A., Gruenwald, N., Bassus, O., Andreeva, N., Zaščerinska, J., \& Melnikova, J. (2018). Impact of Master Programme "Information and Electrical Engineering” for International Students at Hochschule Wismar on Regional Economics: Theoretical Modelling. In: Scientific Printed Works of the 8th International Scientific Conference Perspectives of Economics of Kaliningrad Region and EU Development, June 22-24, 2017, 6-9. Kaliningrad State Technical University, Kaliningrad, Russian Federation.

Ahrens, A., Zaščerinska, J., Melnikova, J., \& Andreeva, N. (2018). An Innovative Method for Data Mining in Higher Education. In: Rural Environment. Education. Personality (REEP). Proceedings of the International Scientific Conference, Volume 11, 11th - 12th May 2018,. Jelgava: Latvia University of Life Sciences and Technologies, Faculty of Engineering. Institute of Education and Home Economics, 17-24.

Ahrens, A., \& Zaščerinska, J. (2014a). Students’ Attitude to Interdisciplinary Research. In: Society, Integration, Education, Proceedings of the International Scientifical Conference, Volume I: Higher Education Institutions Pedagogy, School Pedagogy, Pre-School Pedagogy, May, 23th-24th, 13-23. Rēzekne, Rēzeknes Augstskolas Izdevniecība.

Ahrens, A., \& Zaščerinska, J. (2014b). Factors that Influence Sample Size in Educational Research. In: 2014 ATEE Spring University proceedings Changing Education in a Changing Society, 19-32. Published by Klaipeda University, Lithuania.

Ahrens, A., \& Zaščerinska, J. (2015a). A Comparative Study of Business and Engineering Students’ Attitude to Mobile Technologies in Distance Learning. In: P. O. De Pablos, R. D. Tennyson and M. D. Lytras, Assessing the Role of Mobile Technologies and Distance Learning in Higher Education, Chapter 2, 29-59. IGI-Global.

Ahrens, A., \& Zaščerinska, J. (2015b). Principles of Sampling in Educational Research in Higher Education. Proceedings of the International Scientifical Conference Society, Integration, Education, Volume 1 Higher Education Pedagogy, May, 22nd-23rd, 25-35. Rēzekne: Rēzeknes Augstskolas Izdevniecība.

Ahrens, A., \& Zaščerinska, J. (2021). Post-COVID-19 University Governance in Germany. Journal "Education Reform: Education Content Research and Implementation Problems" (ERCS), Volume 2. (Accepted for publication).

Ahrens, A., Foerster, M., Zaščerinska, J., \& Wasser, I. (2020). European Accreditation Agency's View on Kazakhstan's Engineering and Information Technology Higher Education. SOCIETY. INTEGRATION. EDUCATION Proceedings of the International Scientific Conference. Volume V, 15-25.

Ahrens, A., Gruenwald, N., Bassus, O., Zaščerinska, J., \& Melnikova, J. (2017). Master Programme "Information and Electrical Engineering" for International Students at Hochschule Wismar: Theoretical Framework. In: C.V. Kifor, N. Gruenwald, L. Lobont (Eds), Conference Proceedings of 8th Balkan Region Conference on Engineering and Business Education (BRCEBE) and 10th International Conference on Engineering and Business Education (ICEBE) "Creating a mindset for growth and socio-economic development”, 175-182. Published in Romania by Lucian Blaga University of Sibiu. De Gruyter Online. DOI: https://doi.org/10.1515/cplbu-2017-0023.

Ahrens, A., Purvinis, O., Zaščerinska, J., \& Andreeva, N. (2015). Quasi-Group Decision Making in Higher Education: A Model for Analysis of Binary Students' Behaviour. Scientific Articles: Applied Research in Studies and Practice, Nr. 11 III International Scientific Practical Conference "Trends in Science and Studies Under Conditions of Globalisation", 45-56. Panevėžys College, Panevėžys, Lithuania. ISSN 2029-1280. 
Ahrens et al., 2021. Comparative Studies of Covid-19 Impact on Students'Views on Digital Higher Education

Ahrens, A., Purvinis, O., Zaščerinska, J., Miceviciene, D., \& Tautkus, A. (2018). Burstiness Management for Smart, Sustainable and Inclusive Growth: Emerging Research and Opportunities. IGI Global, 226. DOI: 10.4018/978-1-5225-5442-4.

Ahrens, A., \& Zaščerinska, J. (2012). Perspective of Game Theory in Sustainable Development. In: Stasys Vaitekunas (Ed), ATEE Spring University 2012 Conference 20 Years of Sustainable Development: Learning from Each Other, Lithuanian University of Educational Sciences, Vilnius, Lithuania, May 3-5, 99-108. Publisher: Klaipeda University, Klaipeda, Lithuania. ISSN 1822-2196.

Ahrens, A., \& Zaščerinska, J. (2016). Methodology of Sampling in Educational Research in Higher Education. In: Linda Daniela and Lucija Rutka (Eds), Selected Papers of Association for Teacher Education in Europe Spring Conference 2015, 22-31. Cambridge Scholars Publishing. 978-1-4438-1100-2.

Ahrens, A., Zaščerinska, J., Hariharan, R., \& Andreeva, N. (2016). Educators' Opinion on Webinars in Higher Education. Proceedings of the International Scientific Conference Society, Integration, Education, Volume 1 Higher Education Pedagogy, May, 27th-28th, 15-27. Rezekne: Rezeknes Academy of Technologies.

Ahrens, A., Zaščerinska, J., \& Melnikova, J. (2019). Method for the Construction of Students' Scientific Identity within English for Academic Purposes: The Case of International Students of Master Programme "Information and Electrical Engineering” at Hochschule Wismar. SOCIETY. INTEGRATION. EDUCATION Proceedings of the International Scientific Conference, Volume I, Higher Education, May 24th-25 ${ }^{\text {th }}$, 43-53. Rezekne, Rezekne Academy of Technologies.

Budde, R. (2005). Mexican and Central American L.A. Garment Workers: Globalized Industries and their economic constraints. LIT Verlag Münster.

Cohen, L., Manion, L., \& Morrison, K. (2003). Research Methods in Education. London and New York: Routledge/Falmer Taylor \& Francis Group, 3-45.

Davies, S. (2020). University Policy for Student Digital Equity. University of Bristol. Retrieved from https://www.bristol.ac.uk/media-library/sites/academic-quality/documents/policy/ digital\%20equity\%20final\%2022Sept20.pdf.

Ellis-Haque, Raeesah. (2020). Could the response to Covid-19 help build more inclusive learning environments? Comment 6/07/20. Retrieved from https:/wonkhe.com/blogs/ could-the-response-to-covid-19-help-build-more-inclusive-learning-environments/

Gruenwald, N., Ahrens, A., Zascerinska, J., Melnikova, J., \& Andreeva, N. (2018). SocioCultural Adaptation of International Students of Master Programme "Information and Electrical Engineering” at Hochschule Wismar. In: N. Grueunwald, M. Zakrzewska (Editors), Proceedings of the 5th International Scientific Conference on "Modern Economics”, Vigo, Spain, 33-39. Published by University of Wismar, Germany.

Hariharan, R., Zascerinska, J., \& Swamydhas, P. (2013). A Comparative Study of Methodologies of Teaching Web Technologies to Prospective Teachers in India and Latvia. International Journal of Modern Education Forum (IJMEF) Volume 2, Issue 4 (November 2013), 84-91. Print ISSN 2324-6928, online ISSN 2324-6944.

Kroplijs, A., \& Rascevska, M. (2004). Kvalitatīvās pētniecības metodes sociālajās zinātnēs. Rìga: RaKa.

Krueger, R. A. \& Casey, M. A. (2000). Focus Groups: A Practical Guide for Applied Research, 3rd ed. Thousand Oaks, CA: Sage Publications.

Luka, I., Ludborza, S., \& Maslo, I. (2009). Effectiveness of the use of more than two languages and quality assurance in European interuniversity master studies. Paper presented at the European Conference on Educational Research, University of Vienna, September 28-30, 
2009. Retrieved from https://www.eera-ecer.de/ecer-programmes/conference/2/ contribution/3411/

Mayring, P. (2014). Qualitative Content Analysis: theoretical foundation, basic procedures and software solution. Klagenfurt: Social Science Open Access Repository. Retrieved from https://www.psychopen.eu/fileadmin/user_upload/books/mayring/ssoar-2014-mayringQualitative_content_analysis_theoretical_foundation.pdf

Mayring, P. (2004). Qualitative Content Analysis. In: U. Flick, E. Von Kardoff and I. Steinke (Eds), A Companion to Qualitative Research, 266-269. SAGE.

NCERT. (2020). “Students' Learning Enhancement Guidelines.” Ministry of Education, Government of India.

Phillips, D. (2006). Comparative Education: method. Research in Comparative and International Education, Volume 1, Number 4, 2006, 304-319.

Ramar, H., Zascerinska, J. (2015). Six Sigma: A New Trend in Educational Research. A Comprehensive Approach with Case Studies. GlobeEdit, 124p.

Timmis, S. (2020). Alone together? Digital inequalities and the 2020 student experience of higher education. Retrieved from https://www.researchgate.net/publication/342635308.

UNICEF. (2020). "Guidance on Distance Learning Modalities to Reach All Children and Youth During School Closures. Retrieved from https://www.unicef.org/rosa/reports/guidancedistance-learning-modalities-reach-all-children-and-youth-during-school-closures.

Visco, M. (2020). Technology in Higher Education: Debunking Digital Student Engagement Myths. September 24, 2020. Retrieved from https://www.suitable.co/blog/technology-inhigher-education-debunking-digital-student-engagement-myths. 